\title{
Android-based Instructional Media Development Procedure to Enhance Teaching and Learning in The Age of Disruption 4.0
}

\author{
Singgih Subiyantoro \\ Universitas Veteran Bangun Nusantara \\ Sukoharjo, Indonesia \\ singgihsubiyantoro@univetbantara.ac.id
}

\author{
Anwari Adi Nugroho \\ Universitas Veteran Bangun Nusantara \\ Sukoharjo, Indonesia \\ anwariadinugroho@univetbantara.ac.id
}

\begin{abstract}
This article aims to explain an android-based instructional media development procedure to enhance teaching and learning. At present we have entered a new era that demands technological literacy and data literacy, namely the big data era. People also call it an era of disruption 4.0. Some characteristics of this era are big volume, variety, velocity, veracity, and transitory. The ease of access to information brings benefits as well as various risks. Media development procedures can refer to development models that have been created by experts. One model that can be used is the ADDIE (Analiyz, Design, Development, Implementation and Evaluation) model. Regarding the procedures of developing android-based instructional media will be explained further in Chapter III. The discussion, conclusions, and recommendations contained in this article can be used as consideration for developing or using android-based instructional media, both at school and in college.
\end{abstract}

Keywords: android, disruption era, instructional media, teaching and learning

\section{INTRODUCTION}

In a centralized learning system, the role of a lecturer turns into a facilitator while still mastering the field he is taking. In addition, the material of the teaching material changes. Formerly instructional materials focused solely on knowledge in lectures. Now, lecturers should teach students to have their own learning skills, critical thinking, writing, entrepreneurial spirit, and communication skills. The development of science and technology is so rapid that it encourages every human being to respond and follow all these developments quickly. It takes high ability and willingness with critical, systematic, logical, and creative thinking to understand that development. Currently Android is an interesting trend to study. In the world of education began to be widely used to facilitate learning activities [1].

At present the mastery of technology is the prestige and indicator of a country's progress. The state is said to be advanced if it has a high level of technological mastery, while countries that cannot adapt to technological progress are often referred to as failed states [2].

One of the findings of research conducted on a campus the intensity of smartphone use is very high. Based on data obtained by Christo et al $88 \%$ of students use smartphones for more than 4 hours per day. This can be an encouraging finding as well as a sad finding for educators. It is encouraging if educators are able to capture this data as a potential to develop innovative smartphone-based learning media. On the contrary, it is sad for educators who do not want to see this data as a positive thing, so smartphone technology will only continue to be a means of playing, mesagging, telephone and social media for students.

In some universities, the use of smartphones for learning activities is still relatively low in intensity, still limited to the use of the internet to find and translate languages. Smartphone usage among school students is increasingly increasing, it has even become a trend among students, uncontrolled use of smartphones results in students' learning discipline being disrupted [3]. Most lecturers and students still use laptops, and some even use textbooks to support learning on campus. The use of laptops is quite difficult for students, even many are lazy to carry because of weight and hassle. Lecturers are also quite inconvenient if they have to carry a heavy laptop at any time. The problem that arises when the learning media that is used is inflexible is the low interest in learning students. Therefore, learning media with new packaging are needed in accordance with the learning objectives and characteristics of students at this time so that they are expected to be able to increase their interest and learning achievement. One alternative that is right is the Android-based learning media. This media can be accessed on all smartphone devices so it is flexible to learn, anytime and anywhere. Android smartphones support almost all forms of media (text, images, animation, audio and video). The use of media like this is expected to minimize the negative impact of smartphones which has been more widely used for social media.

The design of an interactive and multi-sensory learning media is a challenge for educational technologists. Media design must offer new insights in new and innovative ways. The use of media must also be able to stimulate change and create a conducive learning environment and make learning more meaningful and responsive to the needs of students.

The results of research on the benefits of mobile learning, Valk, et al. In Kim refer to the use of m-learning with mobile phones in students in developing countries can increase access to learning materials and educational services, 
especially in rural areas and far from cities. Digital learning not only takes place online or in the university classroom but is also situated in high schools, museums, after school programs, home schoolers' living rooms, public libraries, and peer-to-peer universities [4].

In several previous studies relating to students' visual attention and perception, it was reported that many students wanted to make or use learning materials that were more comfortable, so that they could learn whenever and wherever they were.

Based on some resources, technological developments, especially the emergence of mobile learning have changed the students mindset in learning. The campus is not the only place they learn and develop, but only a small part of the vehicle is social and exchange experiences. So it can be said that mobile technology has an important role for students, not just a means of communication but also a tool and source of learning for them.

\section{METHODS}

This article uses the literature study method. This literature relates to the research and development procedure (R\&D) which specifically addresses the ADDIE model developed by Reiser \& Mollenda.

\section{RESULT AND DISCUSSION}

The procedure for developing instructional media with the ADDIE model includes 5 stages, namely analysis, design, development, implementation and evaluation [5]. The following is an outline of the development research procedures carried out.

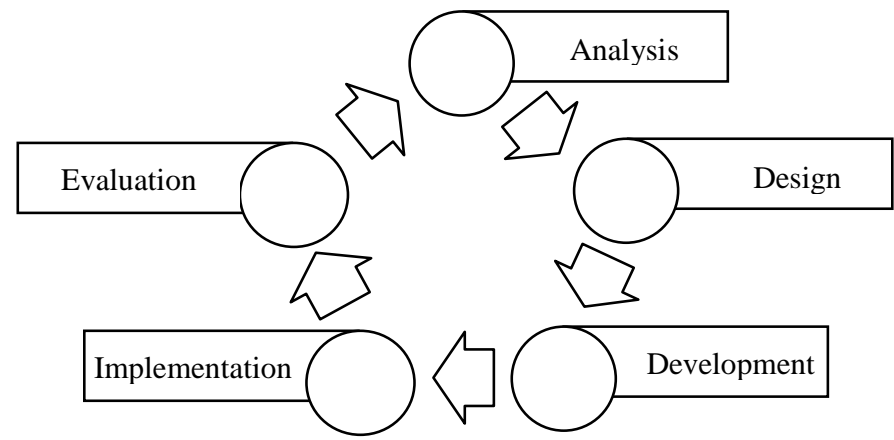

Picture 1. Development Research Procedures

Based on the picture, it can be explained more specific steps from each stage of the research adopted from the ADDIE model as in the following this table.

TABLE 1. THE SPECIFIC DEVELOPMENT STEPS

\begin{tabular}{ccll}
\hline No. & \multicolumn{1}{c}{ Step } & \multicolumn{1}{c}{ Task } & \multicolumn{1}{c}{ Output } \\
\hline 1 & Analysis & $\begin{array}{l}\text { Problem analysis, } \\
\text { learning analysis, } \\
\text { needs analysis }\end{array}$ & $\begin{array}{l}\text { Description of } \\
\text { problems, student } \\
\text { profiles and fields } \\
\text { of study, needs }\end{array}$ \\
2 & Design & $\begin{array}{l}\text { Make development } \\
\text { planning instructions, } \\
\text { collect resources and } \\
\text { materials }\end{array}$ & $\begin{array}{l}\text { Flowchart, } \\
\text { storyboard, draft } \\
\text { materi }\end{array}$ \\
\hline
\end{tabular}

\begin{tabular}{llll}
\hline Development & $\begin{array}{l}\text { Developing media, } \\
\text { expert validation tests }\end{array}$ & $\begin{array}{l}\text { Flowchart, } \\
\text { storyboard, } \\
\text { material draft } \\
\text { Media prototype, } \\
\text { validation result } \\
\text { data }\end{array}$ \\
4 Implementation & Limited trial & $\begin{array}{l}\text { Data resulting } \\
\text { from reviews, } \\
\text { comments from } \\
\text { users }\end{array}$ \\
& & & The final product \\
& Evaluation & $\begin{array}{l}\text { Data interpretation, } \\
\text { product revision }\end{array}$ & \\
\hline
\end{tabular}

\section{A. Analysis}

Most students have advanced mobile phones (smartphones) with an Android-based operating system. This is one proof that students are very closely following technological developments. Unfortunately, this condition is rarely seen as an advantage or potential to support learning activities.

The less optimal use of information technology-based learning media is certainly contrary to the demands of current learning that require high media literacy. Educators and students must know and be able to use them in learning.

Regarding the characteristics of current students, their mobility is quite high. Of course it is necessary to prepare flexible media and teaching materials so that they can be easier to use, anytime and anywhere. Observations also show that students prefer to study individually (independent learning). Optimization of smartphones can be one solution for increasing effectiveness, efficiency, and attractiveness of learning on campus.

\section{B. Design}

In this step the process of designing learning media is carried out through a flowchart and story board. Flowchart is a program flow made from the opening program to exit the program. Examples of media flowcharts that will be developed can be seen in the following figure.

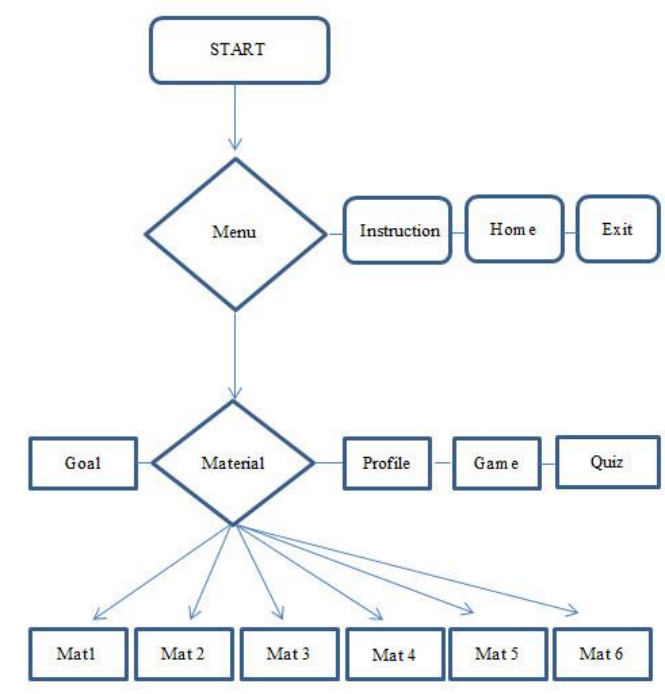

Picture 2. Example of a media flowchart 
TABLE 2. THE EXAMPLE OF A MEDIA STORYBOARD MEDIA

\begin{tabular}{|c|c|c|c|}
\hline No & Judul & Tampilan & Narasi \\
\hline 1 & Menu & $\begin{array}{l}\text { Navigation } \\
\text { button }\end{array}$ & $\begin{array}{ll}\cdot & \text { INSTRUCTION } \\
\bullet & \text { GOALS } \\
\bullet & \text { MATERIALS } \\
\bullet & \text { Ect. }\end{array}$ \\
\hline 2 & Instruction & Teks & $\begin{array}{l}\text { 1. Read the } \\
\text { "INSTRUCTIONS" usage } \\
\text { carefully. } \\
\text { 2. Understand the "GOAL" of } \\
\text { the learning that has been } \\
\text { setect. } \\
\text { 3. Ect. }\end{array}$ \\
\hline
\end{tabular}

\section{Development}

This step is an activity of combining all the materials that have been collected, whether in the form of text, images, or audio in accordance with the flowchart and storyboard that has been made previously. One software that can be used is Adobe CS 6. At the final stage of creation, the file must be published into the APK extension so that it can be installed on all Android smartphones. The product prototype was ready, then validation tests were carried out on two aspects, namely the material aspects and media aspects, so that the media was at least assessed by two validators. The data obtained from this validation test in the form of assessment scores and comments or suggestions for product improvement. The following is an example of a product validation instrument grid that can be used.

TABLE 3. FIXED MATERIAL VALIDATION INSTRUMENTS

\begin{tabular}{|c|c|c|}
\hline No. & Aspek & Indikator \\
\hline 1 & Format & $\begin{array}{l}\text { a. Clarity of learning objectives } \\
\text { b. Suitability of material with learning } \\
\text { objectives } \\
\text { c. Clarity of instructions }\end{array}$ \\
\hline 2 & Content & $\begin{array}{l}\text { a. Compliance of the order of the } \\
\text { b. Concentation of the material } \\
\text { c. Material depth } \\
\text { d. Material area } \\
\text { e. Ease of the material to be explored } \\
\text { f. Suitability of the image with the } \\
\text { g. Examples of suffixes / exercises / } \\
\text { discussions }\end{array}$ \\
\hline 3 & Language & $\begin{array}{l}\text { a. Language behavior } \\
\text { b. Complete sentence structure } \\
\text { c. The effectiveness of the sentence used } \\
\text { d. Consistency in the use of terms }\end{array}$ \\
\hline
\end{tabular}

TABLE 4. FIXED MEDIA VALIDATION INSTRUMENTS

\begin{tabular}{llll}
\hline No. & Aspek & & \multicolumn{1}{c}{ Indikator } \\
\hline 1 & Simplicity & a. & $\begin{array}{l}\text { Images and audio provided are not } \\
\text { excessive / unobtrusive }\end{array}$ \\
& & b. & Ease of navigation buttons \\
& c. & Ease of use instructions \\
& Emphasis & a. & $\begin{array}{l}\text { Images / illustrations are able to } \\
\text { emphasize the material }\end{array}$ \\
& & b. & Example / conclusion / discussion is \\
\hline
\end{tabular}

\begin{tabular}{|c|c|c|c|}
\hline & & & able to give emphasis to the material \\
\hline 3 & Balance & $\begin{array}{l}\text { a. } \\
\text { b. } \\
\text { c. } \\
\text { d. }\end{array}$ & $\begin{array}{l}\text { Suitability of image size } \\
\text { Suitability of letter size } \\
\text { Proportion of text and images / } \\
\text { illustrations } \\
\text { Number of fonts used }\end{array}$ \\
\hline 4 & Format & & $\begin{array}{l}\text { Suitability of the type of letters used } \\
\text { Image quality } \\
\text { The form of animation }\end{array}$ \\
\hline 5 & Color & & $\begin{array}{l}\text { Font color selection } \\
\text { Image color selection } \\
\text { Compatibility of color combinations }\end{array}$ \\
\hline
\end{tabular}
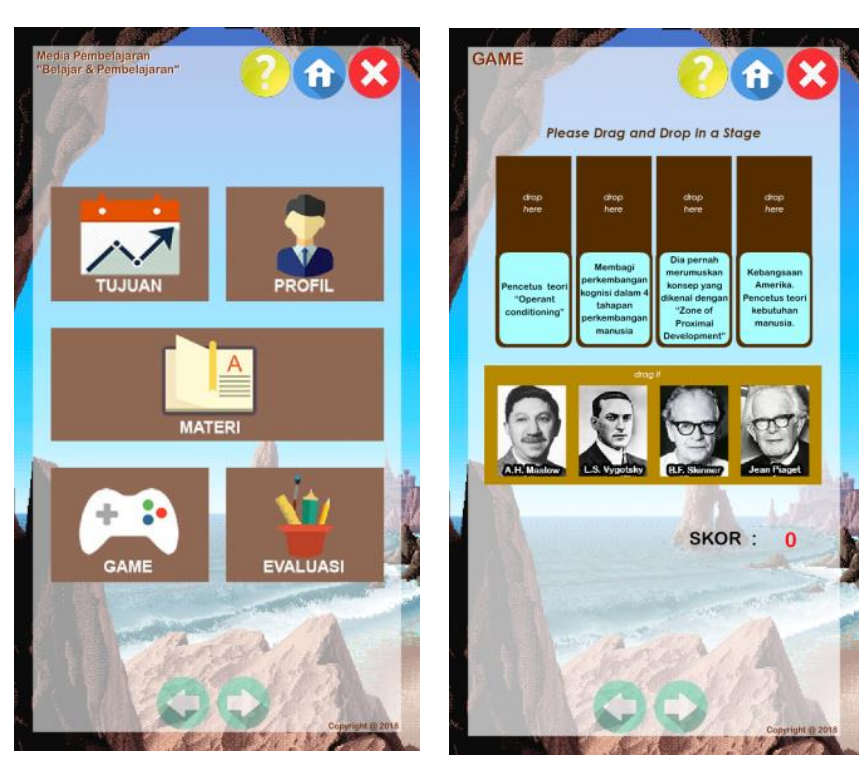

Picture 3. The examples of android-based instructional media

\section{Implementation}

Initial products that have been validated by experts and revised are then tested for practicality. The media was tested on a number of students, around 3-8 students in one-by-one trial sessions, and 10-30 students in limited trial sessions.

\section{E. Evaluation}

At this stage interpretation of the results of one-by-one trials and small or limited group trials is carried out. Test results data in the form of a mean score. This aspect of product appraisal is related to the practicality of using media (material and media aspects). The assessment questionnaire can use $1-4$, or $1-5$ scale.

\section{CONCLUSION}

Media development that adopts the ADDIE model generally uses procedures and steps as described in the previous chapter, through 5 major stages; analysis, design, development, implementation and evaluation. ADDIE is just one development model that can be used as a reference for development research. There are still many other models that can be selected according to needs.. 


\section{ACKNOWLEDGMENT}

Thank you for the Ministry of Research, Technology and Higher Education for funding the research activities of the Beginner Lecturer Research (Penelitian Dosen Pemula) scheme in 2018.

\section{REFERENCES}

[1] M. Oey-Gardiner et al., ERA DISRUPSI. Jakarta: Akademi Ilmu Pengetahuan Indonesia Cetakan II, Juni 2017 Dilarang, 2017.

[2] M. Ngafifi, "Kemajuan Teknologi dan Pola Hidup Manusia dalam Perspektif Sosial Budaya," J. Pembang. Pendidik. Fondasi dan Apl., vol. 2, no. 1, pp. 33-47, 2014.

[3] R. S. Yuni and A. C. Pieewan, "Hubungan Intensitas Penggunaan Smartphone dengan Disiplin Belajar Siswa," J. Pendidik. Sosiol., pp. $1-16,2016$.

[4] T. Scholz, Edited by R. Trebor Scholz. New York: The Institute for Distributed Creativity, 2013.

[5] W. Octaviana, M. Ekosusilo, and S. Subiyantoro, "Pengembangan Multimedia Interaktif pada Materi Pesawat Sederhana untuk Siswa Sekolah Dasar," J. Komun. Pendidik., vol. 2, no. 2, pp. 168-175, 2018. 